\title{
ANG wt Allele
}

National Cancer Institute

\section{Source}

National Cancer Institute. ANG wt Allele. NCI Thesaurus. Code C49352.

Human ANG wild-type allele is located within 14q11.1-q11.2 and is approximately $10 \mathrm{~kb}$ in length. This allele, which encodes angiogenin protein, plays a role in the inhibition of protein synthesis via hydrolysis of cellular tRNAs. 